\title{
The analysis methods of electron-microscopic images for automation of building histograms of nanoparticle size distribution
}

\author{
A. Dubovaya, S. Dukarov, S. Petrushenko, V. Sukhov \\ V.N. Karazin Kharkiv National University, 4 Svobody Sq., 61022 Kharkiv, Ukraine \\ petrushenkokhnu@gmail.com
}

ORCID: 0000-0002-6242-2909, 0000-0002-3527-3661, 0000-0002-7727-9527

DOI: $10.26565 / 2222-5617-2020-33-02$

In that work a describing of automated system is made an introduction, which allow to identify particles, that are look after on electron-microscopic images, and to determine their size, area and length of borders independently. Particle identification is based on a threshold criterion, which has low computational complexity, but has proven to be quite effective when applied to SEM and TEM images. Visual control of correct particle identification is facilitated by colorizing images. The proposed software system has a high performance, and the processing of a typical SEM imagine usually take less than 10 seconds. The proposed approach was tested on different vacuum condensates and shown high efficiency for different SEM and TEM images. It is effective for simple pictures, which are characteristic for samples, formed by melting of sufficiently thick polycrystalline films. This approach can also be used for quantitative processing of images obtained from films condensed by the vapor-liquid mechanism. Usually such images are difficult for automatic processing. Data on the size dependence of the most probable particle radius formed during melting tin films, full width at half maximum of histograms of their size distribution and excess energy, stimulating the process of de-wetting of films were received by using the proposed software. It is shown that particle size distribution for samples obtained by melting initially continuous polycrystalline films is single-mode and has normal character. The ratio of the full width at half the height of the distribution histogram to the most probable particle radius does not depend on the film thickness. Applying offered method for alloys films let to establish the effect of composition on films' de-wetting and to show, that sequential vacuum condensation and subsequent melting are a easy method of forming arrays both single-component particles and alloys particles.

Keywords: SEM, TEM, distribution histogram.

\section{Методи аналізу електронно-мікроскопічних зображень для автоматизації побудови гістограм розподілу наночастинок за розмірами}

\author{
А. Дубовая, С. Дукаров, С. Петрушенко, В. Сухов \\ Харківський національний університет імені В.Н. Каразіна, м. Свободи 4, 61022, Харків, Украӥна
}

У роботі описується автоматизована програмна система аналізу електронно-мікроскопічних зображень, яка дозволяє визначати характерний розмір, площу і довжину границі частинок, що спостерігаються на електронно-мікроскопічних зображеннях. Виділення частинок на рівні фону здійснюється на основі порогового критерію, який має невисоку обчислювальну складність, проте виявляється достатньо ефективним при застосуванні до зазвичай контрастних SEM та TEM зображень. Використання такого простого алгоритму забезпечує пропонованій програмній системі високу швидкість роботи і дозволяє виконувати кількісну обробку типового SEM зображення протягом не більше 10 секунд. Розроблене програмне забезпечення показало високу ефективність не лише для простих зображень одержуваних від зразків, утворених плавленням полікристалічних плівок товщина яких перевищує критичне значення, а й дозволило провести кількісну обробку SEM зображень зразків, сконденсованих за механізмом пара-рідина. Незважаючи на те, що для плівок, одержаних конденсацією речовини в переохолоджену або термодинамічно стабільну рідку фазу, властиві високі коефіцієнти заповнення підкладки плівкою, які ускладнюють виділення часток на рівні фону і їх відділення одна від одної, запропонований підхід дозволяє успішно вирішити завдання кількісної обробки таких зображень. Апробація нашої програмної системи проведена на прикладі бінарних плівок In-Pb змінного складу і плівок олова змінної товщини, які конденсовані на аморфні вуглецеві та молібденові підкладки. Отримано дані про розмірну залежність найбільш ймовірного радіусу частинок, які утворюються при плавленні плівок олова, напівширини гістограм розподілу частинок за розмірами і надлишкової енергії, яка стимулює термічне диспергування плівок. Застосування запропонованого програмного забезпечення для бінарних сплавів дозволило встановити вплив складу на процес термічного диспергування вакуумних конденсатів і показати, що послідовна вакуумна конденсація і подальше плавлення є зручним методом формування масивів однорідних частинок бінарних сплавів.

Ключові слова: SEM, TEM, гістограма розподілу за розмірами. 


\title{
Методы анализа электронно-микроскопических изображений для автоматизации построения гистограмм распределения наночастиц по
}

\author{
размерам \\ А. Дубовая, С. Дукаров, С. Петрушенко, В. Сухов \\ Харьковский национальный университет имени В.Н. Каразина, м. Свободы 4, 61022, Харьков, Украина
}

В работе описывается автоматизированная система анализа электронно-микроскопических изображений, позволяющая определять характерный размер, площадь и длину границы частиц, наблюдающихся на электронномикроскопических изображениях. Выделение частиц на уровне фона выполняется на основе порогового критерия, который имеет низкую вычислительную сложность и оказывается достаточно эффективным при применении к SEM и TEM изображениям. Использование низкозатратного алгоритма обеспечивает предлагаемой программной системе высокую производительность и позволяет выполнять обработку типичного SEM изображения за время не более 10 секунд. Предложенный подход показал высокую эффективность не только для простых изображений, получаемых от образцов, образованных плавлением поликристаллических пленок, но и позволил выполнить количественную обработку SEM изображений пленок, сконденсированных по механизму пар-жидкость. Несмотря на то, что для образцов получаемых конденсацией вещества в переохлажденную или термодинамически стабильную жидкую фазу, характерны высокие коэффициенты заполнения подложки пленкой, которые усложняют выделение частиц на уровне фона и их отделение друг от друга, примененный подход позволяет успешно решить задачу количественной обработки таких изображений. Апробация предложенной программной системы проведена на примере бинарных пленок $\mathrm{In}-\mathrm{Pb}$ переменного состава и пленок олова переменной толщины, конденсированных на молибденовые и углеродные подложки. Получены данные о размерной зависимости наиболее вероятного радиуса частиц, образующихся при плавлении пленок олова, полуширины гистограмм распределения частиц по размерам и избыточной энергии, стимулирующей термическое диспергирование пленок. Применение предложенного метода для бинарных сплавов позволило установить влияние состава на процесс термического диспергирования пленок и показать, что последовательная вакуумная конденсация и последующее плавление являются удобным методом формирования массивов однородных частиц бинарных сплавов.

Ключевые слова: SEM, TEM, гистограма распределения по размерам.

\section{Introduction}

Electron microscopy is one of the main tools available to modern researchers. With the help of SEM and TEM methods it became possible to study process, happened in biological objects, structural materials, various nanosystems, etc. Electron microscopy has received the most powerful push recently when the combination of high-resolution microscopy, allowing observing crystal lattice, with in situ technologies brought research to a fundamentally new level. Using a combination of such technics, it is possible to establish unique features of the phenomena occurring in nanosystems, for example, metalinduced crystallization $[1,2]$, crystallization of supercooled melts $[3,4,5,67,8]$, solubility $[9,10,11]$, etc.

At the same time, the urgent task of modern researchers remains to analyze the obtained electron microscopic images. Especially it is stay important in studying integral parameters of a nanostructure pattern, which usually requires processing a lot of images. The growing interest of applied researches in arrays of metal particles, which are considered as a functional element of chemical catalyst, photocatalytic generators and touch devices [12, 13, 14, $15]$, contributes not only the developing of new ways of forming functional nanomassives, but also compels them to improve methods of their study.

A particles size distribution has the main meaning for a lot of applied tasks. In particular, frequently it is necessarily to know the most probable particles' radius, full width at half maximum of histograms of their size distribution and a received particles' fractality degree. However, reliable plotting of histograms requires measuring dimensions of the size of an extremely large number of particles. According to Sturges rule [16], a reliable construction of histogram, subdivided only on seven intervals, can be completed only after receiving more than one thousand experimental points. For a long time, such problems were solved with a help of various approximate and statistical methods, but today the development of digital technologies allows to automate the analysis of micrographs.

Despite the availability of many software tools, designed for digital processing of various images, none of the available solutions can be called completely satisfactory. Thus, multifunctional programs designed for processing "everyday" images are limitedly applicable to tasks arising for researchers. And special software packages, usually supplied as additional options by manufacturers of electron microscopes, do not provide the necessary flexibility and have a high price, which limits the possibility of their use. In this regard, the task of developing a software package that makes it possible to ensure automation of the process of constructing histograms from electron microscopic images with minimal costs is becoming urgent.

\section{Automation methodology of constructing histograms} process 
One of the initial tasks, which arise in the process of automation of processing electron microscopic images, is allotment of interested objects on the image. Today a lot of algorithms for determination of the visually observed boundaries have been developed, many of which are based on Canny operator [17]. However, despite of high efficiency of the such algorithms, they have excessive computational complexity and in using in real SEM images do not provide needed efficiency. That is why in solving our task it was possible to use the simplest threshold criterion in view of the high contrast of SEM images for allotment objects from background highlight. Its value is manually set by the operator before image processing. Next, pixel-by-pixel passage of the entire electron microscope image and the division of pixels into two classes: background pixels and pixels of desired objects are realized. Actually, that processing phase converts the original image with a big deep of color in binary picture. Despite the algorithm's simplest character, it lets reliably and reproducible highlight particles, looked after in island films. It is such samples that are the main object, the study of which is supposed to be performed using the proposed software package. Single background's pixels, brightness of which because of random effects can lead to their belonging to information objects, they will be pearl off on the last algorithm's stage easily by the setting up of minimum area threshold, starting from which the object will be pearl off to physical particles. Usually it's enough to set up the threshold on the level of 5-10 pixels. Practically, that can help to pearl off the effect of digital noise even on very noisy images.

The next step of the proposed algorithm assumes to assign each of the particles, that have been found on the previous stage, its unique color, which let to work with each one independently. It gives an opportunity to code more than 16 million unique particles, that is more than enough for images, encountered in practice, by using RGB space. For solving the task, it was turned out to be convenient to use the standard pouring function, available in most popular integrated development environment. At this step, pouring is applied to each previously identified particle during pixel-by-pixel image pass, which assigns all pixel population, being in contact, unique significance of color, that is further used as particle's identifying index. From this point on, we can abandon to work with image and for computing optimization go to work with twodimensional array of the appropriate type.

The next image's processing stages are defined to determine particle's size and can be completed with a help of various technics, one of each is fraught with a number of difficulties. So, a series of consecutive passes of the all two-dimension array, with the goal to count the number of pixels, belonging to each of the particle, excessive computational cost. It turned out to be the most rational to measure the size of all particles within a single image pass. For this was use one-dimension array integer type, and color, previously assigned to particle, was as an index array's element. Despite the large size of the arrays, especially in noisy images, leading to high memory consumption, it allowed providing full SEM image's processing in size of 1500-by- 1500 pixels during 5 seconds using slow computer.

Along with a particle area proposed program system let to determine length of their boundaries independently. Final version's screenshot of the program system, letting to determine length and square of the boundary each of the particles, found on the image automatically, is submitted on the fig.1. Received values (particles' square, length of their boundaries and coordinates of conditional centers) are saved in text files and they can be processed by off-site programs for solving specific scientific tasks hereinafter.

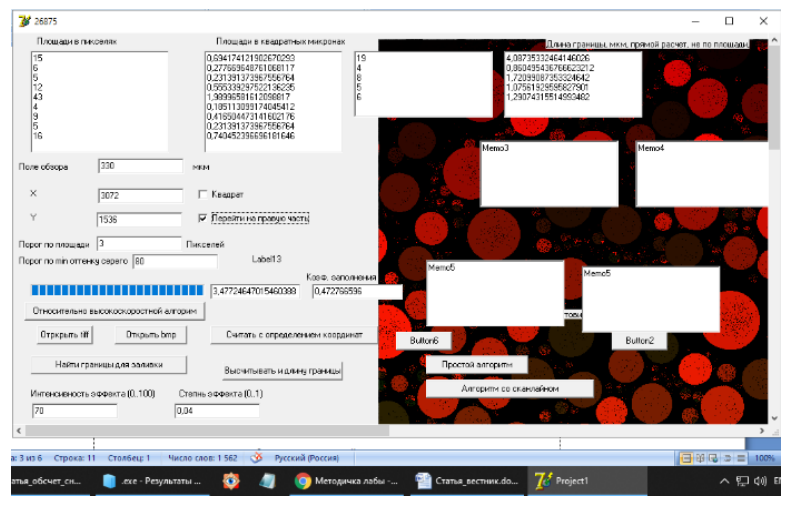

Fig. 1. Screenshot of the working window of the program designed for automatic image analysis

\section{Testing of the developed system}

Films of fusible metals and alloys, condense ' vacuum on different substrates (molybdenum b amorphous carbon) were chosen for testing offered program complex. Samples were prepared in the conditions of a high vacuum, created with oil free pumping out system. After that, the films, deposited by the vaporcrystal condensation mechanism, were exposed to shortterm heating, provided their melting. A detailed analysis scientific results, received during studying films $\mathrm{Sn} / \mathrm{C}$ and $(\mathrm{In}-\mathrm{Pb}) / \mathrm{Mo}$, is given in $[18,19]$. It is appropriate to stop only on the separated aspects of digital processing electronmicroscopic images. SEM image of self-organized structures formed after melting of polycrystalline films is shown on the fig.2. It's clear that, as it was expected after work's results $[18,19,20]$, the films, after melting on the poorly wettable substrate, are consisted of disparate spherical particles. 


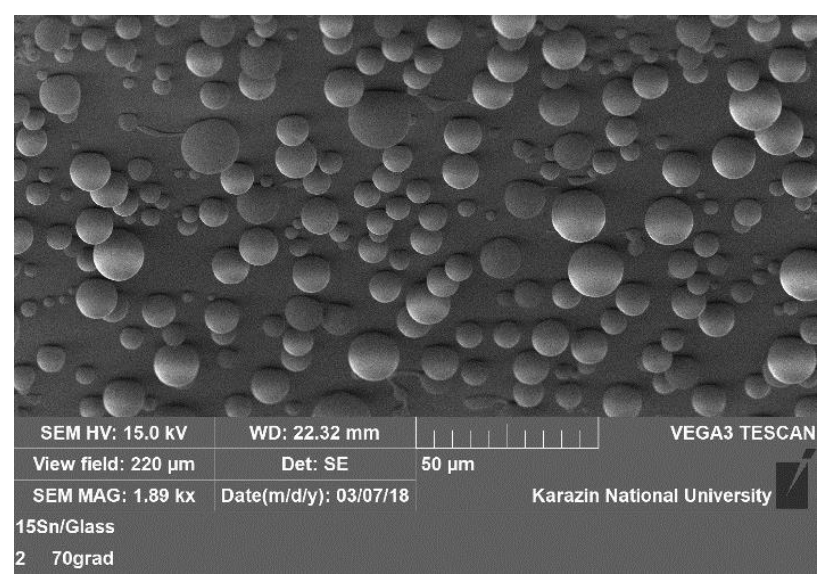

Fig. 2. SEM image of self-organized structures formed after melting of polycrystalline films

Visually work results of the offered program are illustrated on the fig. 3, on which SEM image are presented after carrying out color uniqueness particles. The realized digital processing system turns out to be efficient not only for rather simple island films with a low coverage (Fig. 3a), but also for a more complex image, which is characterized by high coverage and a small distance between particles (Fig. 3b, c).

Results of quantitative processing images are presented on the fig.4, on which particle size distribution histograms are shown, occurring during forming island films. As we see, system particles' $(N)$ quantity, radius of which $(R)$ gets into the selected histogram step $(\Delta R)$, increases quickly with reducing $R$ in such systems.

But, despite increasing particles number of a small radius, substance volume, which is concentrated in them, can be insignificant. In this time, not an absolute number particles value, getting into one or the other histogram step,

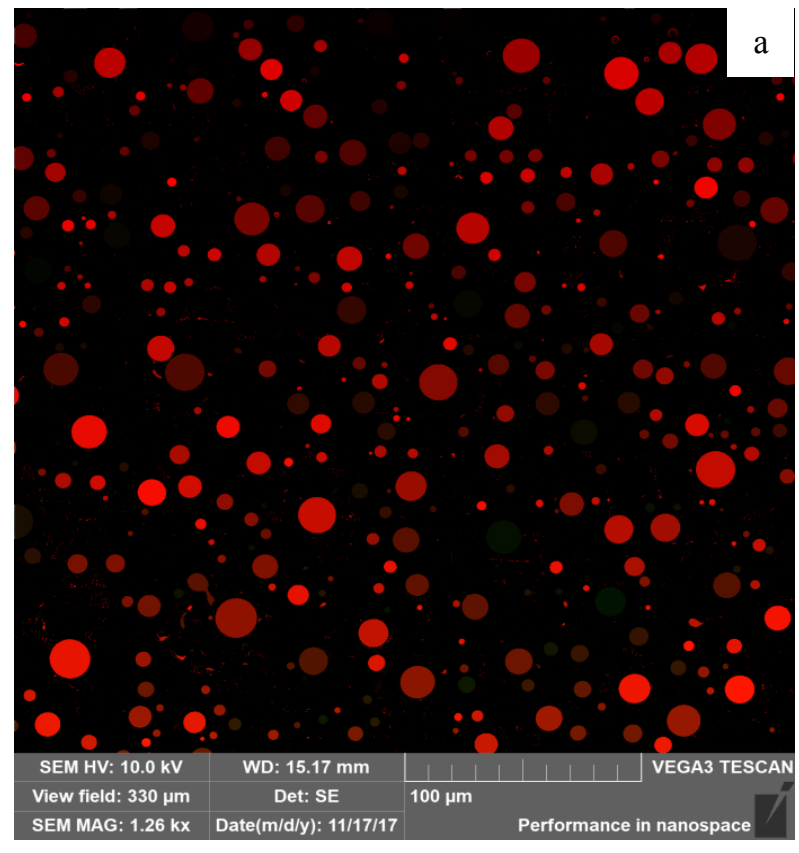

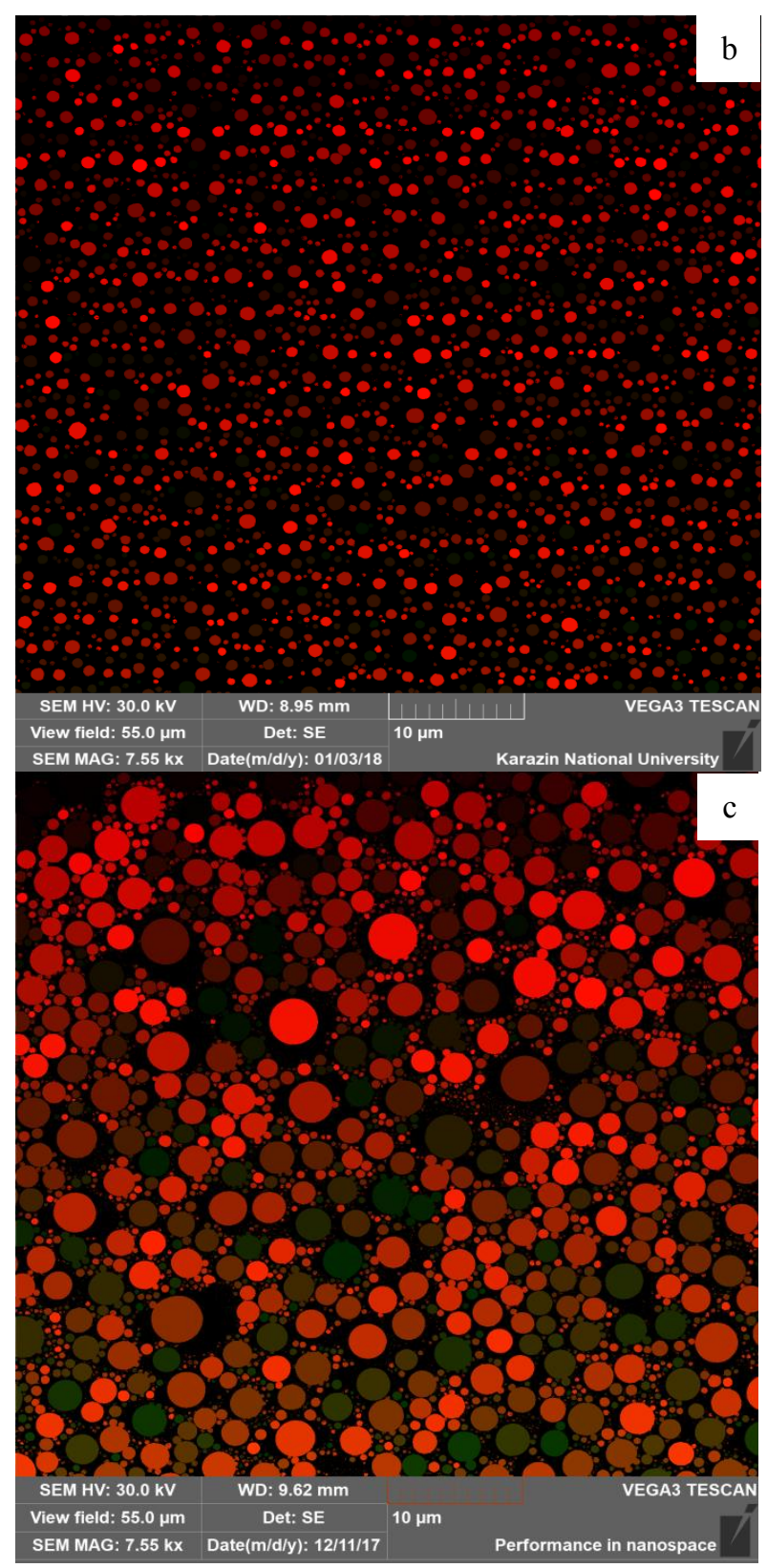

Fig. 3. Processed SEM images of $\mathrm{Sn} / \mathrm{C}$ films obtained by melting films condensed by the vapor-crystal mechanism (a, b) and directly deposited into the liquid phase (c).

but sample's mass distribution over the particles of various sizes has a great importance for many practical apps and for describing integral properties of the islands structures. Therefore, to construct histograms in $[18,19]$ the value $W=\frac{4}{3} \frac{\pi N(R) R^{3}}{A \Delta R}$ is plotted along the vertical axis. Here $N(R)$ is the number of particles, the radius of which falls into the selected step of constructing the histogram $\Delta R ; A$ is the area of the image, from which the histogram calculation was carried out. The $\mathrm{W}$ value keeps information about substance amount, that is concentrated in particles, getting into chosen histogram step. Numerically $W$ is equal to that film thickness, which would 
turn out if all substance, concentrated in particles, that get in size $\Delta R$ interval, was evenly distributed over the substrate with the area A.

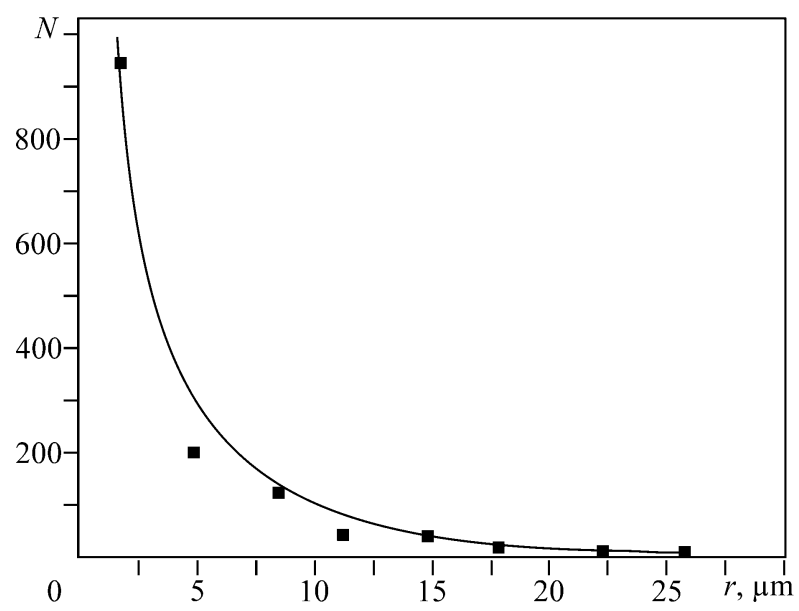

Fig. 4. Dependence of the number of particles falling into the step of the histogram on their average radius

Histograms' example, received with that normalization, is shown on the fig. 5. As we see, such particle size distribution for samples, obtained by melting initially continuous polycrystalline films, is single-mode and has normal character. Size and concentration effects were studied in films $\mathrm{Sn} / \mathrm{C}$ и ( $\mathrm{In}-\mathrm{Pb}$ )/Mo by analyzing of normalized in a such way histograms [18, 19]. Particularly,

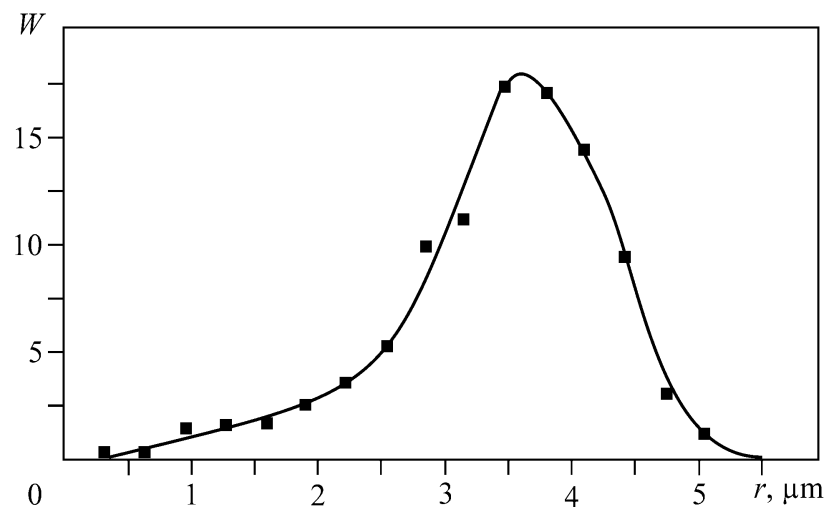

Fig. 5. Dependence of relative extension from temperature

in [18] size dependence of the most probable radius and, full width at half maximum of histograms was built. It is shown that the ratio of these quantities does not depend on the film thickness. Size dependence of excess energy received in work [18], that gets out of during thermal dispersion of the sample, shows that for films, thickness of which is less than critical, that value fast aims to zero. This indicates that rather thin samples form island and actually equilibrium structure in condensation process. Study of the concentration dependence of de-wetting parameters, performed in [19], showed that full width at half maximum of histograms and the most probable particle radius, come into being during dispersion of binary films $\mathrm{In}-\mathrm{Pb}$, received by consistent condensation, had for alloys, having from 20 to 80 mass $\% \mathrm{~Pb}$, permanent value.

\section{Conclusion}

A system of automatic digital processing of electronmicroscopic images was developed and tested, getting an opportunity to determine area and length of the boundary each of the particle independently. Processing of typical electron-microscopic image takes about 5 seconds. It lets to process large amount of data, needed for studying statistic regularities of forming structures, appeared in high-dispersed samples. Proposed software approach was tested on the number of systems and it let to set important features of self-organization process, which lead to forming ordered structure during annealing of condensed films.

\section{References/Literature}

1. D. Janke, F. Munnik, J. Julin, et al. Carbon, 159, 656-667. (2020).

2. A.P. Kryshtal, A.A. Minenkov, P.J. Ferreira. Applied Surface Science, 409, 343-349. (2017).

3. M. Wu, Q. Zhang, B. Zhao, et al. J Therm Anal Calorim, 135, 2995-3003. (2019). https://doi.org/10.1007/s10973-0187523-1

4. G. Kellermann, A. Gorgeski, A.F. Craievich, L.A. Montoro. Journal of Applied Crystallography, 48 (2), 520-527. (2015).

5. S.V. Dukarov, S.I. Petrushenko, V.N. Sukhov. Materials Research Express, 6 (1), 016403. (2018).

6. S.V. Dukarov, S.I. Petrushenko, V.N. Sukhov. Vacuum, 122 208-214. (2015).

7. H.F. Degenhardt, G. Kellermann, A.F. Craievich. Journal of Applied Crystallography, 50 (6), 1590-1600. (2017).

8. D.A. Basha, N. Ravishankar, K. Chattopadhyay. Journal of Materials Science, 52 (9), 5194-5207. (2017).

9. S. Bogatyrenko, A. Kryshtal, A. Minenkov, A. Kruk. Scripta Materialia, 170, 57-61. (2019).

10. S.I. Bogatyrenko. Technical Physics, 59 (9), 1374-1377. (2014).

11. A.P. Kryshtal, S.I. Bogatyrenko, R.V. Sukhov, A.A. Minenkov. Applied Physics A, 116 (4), 1891-1896. (2014).

12. K. Sytwu, M. Vadai, J.A. Advances in Physics: X, 4 (1), 1619480. (2019).

13. O. Lupan, V. Postica, T. Pauporté, et. al. Sensors and Actuators A: Physical, 296, 400-408. (2019).

14. Y. Wu, Y. Yi, Z. Sun, et al. Chemical Engineering Journal, 390, 124515. (2020).

15. T. Chen, J. Yu, C. Ma, et. al. Chemosphere, 248, 125964. (2020).

16. H.A. Sturges. Journal of the american statistical association, 21 (153), 65-66. (1926).

17. J. Canny. IEEE Transactions on pattern analysis and machine intelligence, (6), 679-698. (1986).

18. S. V. Dukarov, S. I. Petrushenko, V.M. Sukhov, I. G. Churilov Metallofiz. Noveishie Tekhnol., 41 (4), 445459. (2019).

19. S.V. Dukarov, S.I. Petrushenko, I. Churilov, A. Lyalka, Z. Bloshenko, V. Sukhov. Microstructure and Properties of Micro-and Nanoscale Materials, Films, and Coatings (NAP 2019) (Springer, Singapore, 2020) pp. 379-388.

20. S.I. Petrushenko, S.V. Dukarov, V.N. Sukhov, I.G. Churilov Journal of Nano-\& Electronic Physics, 7 (2), 02033. (2015). 